\title{
Towards the Privatization of Global Governance?
}

\author{
Oscar Ugarteche ${ }^{1}$
}

Published online: 2 June 2017

(C) Society for International Development 2017

\begin{abstract}
The article analyzes the trend towards the privatization of global governance resulting from the crisis of multilateralism and the shift from the multilateral international system, based on nation States, to a global private market-based system with global private sector actors. The underlying question throughout it is if global public goods can be regulated by private global institutions. The tensions arising from this are expressed as the weakness of the multilateral system created with the Pax Americana after WWII.
\end{abstract}

Keywords Multilateralism · Bilateralism · Governance · Privatization · Power structure - Global political economy

\section{Introduction}

The creation of multilateralism with imbedded liberalism, as defined by Ruggie (1992), was based on the predominance of the United States (US) as an economic, military, political, diplomatic and technological leader. But multilateralism as expressed by International Financial Institutions (IFIs) and the United Nations (UN) system was designed around pax Americana and an international economic and political structure that does not exist anymore. The International Trade Organization was aborted in 1947 because the US felt the other block had too much influence in its design and thus preferred to maintain the General Agreement on Tariffs, an instrument that was meant to lead

Oscar Ugarteche

ugarteche@iiec.unam.mx; ougarteche@gmail.com

1 Instituto de Investigaciones Económicas, Mexico, DF, Mexico towards the creation of the International Trade Organization (ITO), as the end result of the Bretton Woods' threelegged effort. The US Government objected the ITO and the GATT became an end in itself. The Bretton Woods conception comprised an International Monetary Fund (IMF) to prevent a crisis like that of 1929, an international bank for reconstruction, to rebuild Europe and Japan after the war, and an international trade organization so that beggar-thy-neighbour policies would never be introduced again. The US made it clear that the rules were made for the world but that the US was to be the exception that confirmed the rule. They could not be applied to the US because no one can give rulings to the US. This is what is called the principle of US exceptionalism. 'The fact that so many Americans persist in thinking in terms of a mission, however one judges this fact, is very likely today to be an example of exceptionalism in the social scientific meaning.' (Ceaser 2012: 7-8).

The emergence of new powers and new realities after 1990 has revealed the multilateral system as outdated. The Soviet bloc disappeared and China introduced itself as a new leading international economic actor changing the world reality completely. International trade took on a new impetus as the former Soviet bloc countries, under US guidance, entered the global markets and China emerged as an export factory. This paved the way for the resurgence of the liberal concept of export-led growth and did away with all policies related to the development of domestic markets. The role of the state in development was abolished through the Washington Consensus and the market became the primary development agent. The role of the state has been reduced to rescuing the financial sector and promoting private investment. Simultaneously, financial deregulation took over economic policy which together with major technological change introduced by the Internet resulted in 
a more informed world with increasing trade of goods and services, including financial services and an increasing flow of people, both migrants and visitors.

The end product was globalization and spread of financial markets between 1990 and 2008, with the growing power of major financial firms, markets and institutions, and the theoretical shift from the relevance of production for growth to the relevance of finance, inflation targeting and open economies. Simultaneously, the demise of Soviet power meant for some a unipolar world and that security would be provided by the sole military power left. A continuing discussion followed about the shape of a unipolar world and its contents (Krauthammer 1991; Wohlforth 1999; Monteiro 2014).

The growing power of the private sector-and especially its financial segment—can be seen at play in the crisis of multilateralism in three realms: trade, finance and climate change.

\section{The Crisis of Multilateralism in Trade}

The concept of outsourcing replaced Fordism and a postFordist world came into being, with global lines of production now known as global value chains. This requires very open markets and the revolution of transport so that inputs can arrive just on time for the next stage of the value chain. It in turn gave way to the creation of the World Trade Organization in 1995, which meant finally having a set of rules for international trade and investment and not only tariffs. Here the problems began.

The background to investment agreements begins in 1988 when the OECD had initiated negotiations to turn existing non-binding investment agreements into binding ones. Officially, those negotiations were discontinued because of the US refusal to give Canada an exemption on the national treatment on culture. The reason behind appears to have been the growing ambition of some negotiation partners (particularly the US) to launch negotiations on more comprehensive agreement on liberalising investment flows (Blanya, Doherty, Hoedeman, Ma'anit, Wesselius 1998) or as the European Round Table of Industrialists (ERT) put it: to 'lock in the process of liberalisation' (ERT, European Industry: A partner for the Developing World. Foreign Direct Investment as a Tool for Economic Development and Co-operation-Suggestions for Future Improvement, 1993, p 35). (Tieleman 2000: 8, footnote 4)

In the mid-1990s, the US and EU promoted the creation of a Multilateral Investment Agreement (MIA) through the OECD. The work began at the Paris OECD ministerial meeting in June 1994 and it would have given multilateral corporations increasing power. The US and the EU wanted to assure foreign investors they had 'the right' to invest without local government approval, with limited refutability by the host country. The MIA, ensured 'national treatment' to foreign investors, i.e. equal treatment to foreign and domestic investors, including access to credit, research and other subsidies. The idea was meant to become universal in Singapore in the 1996 WTO ministerial meeting. In the ministerial declaration it is stated that it is necessary to 'establish a working group to examine the relationship between trade and investment'. According to Martin Khor, the rich nations wanted the WTO to start discussions on investment issues, as a prelude (they hoped) to negotiating a multilateral investment agreement to give just such rights to their corporations, while developing countries were against a MIA as it could undermine their national economic interests (Khor 1996). Negotiations continued at the OECD with the three groups-business, government and non-governmental organizations-until April 1998, when they were discontinued because of NGO opposition. This is written and analyzed by Kobrin (1999) and Henderson et al. (2002). It was later followed by two very major protests in Seattle 1999 and Genoa 2001.

Harding and Kohl suggest that the secretive nature of the negotiations and the strong bias in favour of the investor countries led to the breakdown of the negotiations in 1998. Attempts were made after in the 2003 WTO Ministerial Meeting in Cancun to restate the MIA.

In the face of the, at least temporary, defeat of a push for multilateral rules on investment, the US began pushing something called the Trade in Services Agreement (TISA) plus Bilateral Investment Treaties (BITs). The Trade in Services Agreement (TISA), according to the Canadian Government website on Global Affairs, is a services-trade only agreement currently being negotiated since March 2013 by 23 Members of the World Trade Organization (WTO), including Canada. TISA negotiations are conducted outside the WTO framework, building upon the General Agreement on Trade in Services (GATS) with the objective of transforming it to a WTO agreement by broadening participation to all WTO Members. Its objective is to do away with barriers trade in services, particularly financial services, telecommunications, electronic commerce, movement of natural persons, international maritime services, air transport services, state-owned enterprises, and express delivery services, among others.

Bilateral Investment Agreements are the other way around the obstacles to MIA. According to the Office of the US Trade Representative (USTR), U.S. BIT framework requires that investors receive national treatment. It establishes clear limits on the expropriation of investments 
and provide for payment of prompt, adequate, and effective compensation when expropriation takes place. It provides for the transferability of investment-related funds into and out of a host country without delay and using a market rate of exchange. It restricts the imposition of performance requirements, such as local content targets or export quotas. It gives investors the right to engage the top managerial personnel of their choice, regardless of nationality. Finally, it gives investors the right to submit an investment dispute with the government of the host country to international arbitration. There is no requirement to use that country's domestic courts. The replacement of the MIA with BITs and TISA completely did away with the role of the WTO as a multilateral forum on investments and services. The existence of a space for a more balanced division of power has been broken and transnational corporations negotiate through their Governments individually using the multilateral institution simply for the presentation of results.

Another new factor helping make multilateralism outdated was that the US began pushing again the late nineteenth century idea of Pan-Americanism (1889). It returned as the Enterprise for the America's Initiative in 1990 (under the presidency of George H. W. Bush) and was later transformed into the Free Trade Agreement of the Americas (FTAA) (Bill Clinton and George W. Bush) negotiated between 1994 and that in 2005 was rejected by the emerging Latin American countries that preferred regional integration without the United States. The new path the US took to obtain Pan-American integration was bilateral free trade agreements using the mold of the 1987 US Canada Free Trade Agreement, particularly for the car industry. This was followed by North America Free Trade Agreement (NAFTA), including Mexico. The NAFTA was then followed by Chile (2004), Peru (2009), Colombia (2012) and Panama (2012). The sum of all of this is a symptom of the crisis of multilateralism in the trade sphere. It is also a sign of the US struggle to retain and regain leadership in the midst of a multilateral institutional crisis.

The surge of the newly elected US President (2017) in the international trade arena has been observed in two areas sowing the crisis of multilateralism: initially he eschewed the Trans Pacific Partnership (TPP) designed by President Obama to counter Chinese influence in the Pacific region. The TPP was not designed within a multilateral framework and in spite of that the new president decided to eliminate it. He then followed with a discourse on how the US was victim of the Mexicans, ignoring the process that led to the NAFTA and the role of President Bush Senior. Finally, he threatened to split this trilateral agreement into two bilateral ones, and threatened to add a 20 percent border tax until the Canadian Government warned of the effects it would have on US prices. Trump is the expression of the existing crisis in multilateralism and international relations and the return of geopolitics and geoeconomics. The reverse trend is that Mexico is pushing for Alliance of the Pacific (AofP) countries to sign a free trade agreement with MERCOSUR. This would reinvigorate Blainés concept of Pan Americanism, as all AofP countries have free trade agreements with the US.

\section{The Crisis of Multilateralism in Finance}

The World Bank shifted its policy from project-based finance to policy-based finance (Mosely et al. 1991; Toye and Toye 2004) in the mid-1980s. The problem was that project-based finance was not successful and a major debt crisis emerged in 1981 generating problems for the Bank. This led to a reconsideration of its role and the new mandate agreed upon was the introduction of economic policy. This meant 'new rules of the game for a new world', as the Bank wrote in its 1985 World Development Report. This happened at the same time as the IMF changed its monetary policy. The final step was a procedural one (Griffith-Jones 1988): for defaulted debts to be negotiated the procedural conditions was first to go the IMF. However, the IMF had as a condition for the debtor country to go the World Bank's way. As both sets of conditions and supplementary policies were applied, then and only then could the debt or state negotiate with the Paris Club (of official creditors) and the London Club (of private creditors). Soon after, between 1980 and 1993, financial deregulation was progressively introduced in the US and the rest of the world. In 1994 a major currency crisis occurred in Mexico, followed by another one in Thailand (East Asian Crisis of 1997), Russia (1998), Brazil (1999) and Argentina (2001). In the crises taking place since 2007 and onward, the US Federal Reserve (Fed) signed swap agreements with thirteen countries for a total amount of US\$ 755 bn and the Chinese Central Bank with six other countries for a total amount of US\$ 650 bn, while the European Central Bank (ECB) had four for a total amount of US\$ 31.5 bn. The Asian central banks have constructed the Chiang Mai Multilateral Fund with a total amount of US\$ $450 \mathrm{bn}$. All of this is a clear symptom of the perception of the IMF as being inadequate. The IMF response has been the design of a flexible credit line that has so far been subscribed only by Mexico, Poland and Colombia. The dimension of the new problems outstretched existing institutions and led to a redefinition of the international set of rules and institutions from the top down.

Another angle related to debt negotiations became notorious. Problems with Argentina's sovereign debt, restructured in 2005 with a sharp haircut, led to a debate on how debts should be restructured and where. The evidence that London Club negotiations in New York were not sufficient was clear as private creditors got different 
treatments than, say, official creditors, while multilateral creditors were never considered for haircuts given their preferred creditor status. The conclusion made by Raffer (1990) was that the solution of defaulted public debt needed a board of arbitration inspired to the Chapter 9 of US bankruptcy legislation (applicable to insolvency of municipalities). This led to a larger discussion during the first decade of the twenty-first century where Ugarteche and Acosta (2007) proposed a multilateral board of arbitration using a new international trade law, in the spirit of the United Nations Commission on International Trade Law (UNCITRAL). This idea was taken in by the Argentine Government as the New York court ruled against it in a case made by a number of distressed market creditors (popularly known as 'vulture funds'). The discussion began in 2013 at the General Assembly level and reached an important milestone in 2014, when 124 countries voted in favour, 13 against and 40 abstained on a resolution to begin a process to establish a multilateral legal framework on sovereign debt restructuring. The discussion triggered the International Capital Market Association (ICMA 2013) to call for an initiative which concluded:

11. ICMA believes it is appropriate at this time to propose new standard for aggregated collective action clauses for inclusion in all government securities (that are not otherwise subject to the mandatory euro area model collective action clause), and to replace the existing form of Collective Action Clause for Sovereign Notes published in October 2004 currently found in the ICMA Handbook (under ICMA Standard Documentation VIII).

At the UN, the Argentine government pressed further in 2015, where the process set in motion in 2014 led to adoption of a set of 'Basic Principles on Sovereign Debt Restructuring' (UN General Assembly, 69th General Assembly, 108th meeting, 9 September, 2015) by 136 votes in favour, 6 against and 41 abstentions. With the election of the new government in Argentina, this initiative lost its main backing and the end result is that from an international mechanism proposed by Argentina with major world support what is left is the ICMA Collective Action Clause. This is a clear example of the privatization of governance. The weight of the financial markets expressed in the opposition votes of the US, UK, Israel, Germany, Japan, is more important than the will of the majority.

\section{The Crisis of Multilateralism and Climate Change}

The United Nations Framework Convention on Climate Change (UNFCCC) was introduced in 1994 with the objective to stabilize greenhouse gas concentrations 'at a level that would prevent dangerous anthropogenic (human induced) interference with the climate system'. It states that 'such a level should be achieved within a time-frame sufficient to allow ecosystems to adapt naturally to climate change, to ensure that food production is not threatened, and to enable economic development to proceed in a sustainable manner'. (The United Nations Framework Convention on Climate Change 1994).

The Conference of the Parties (COP) of the UNFCCC has met regularly since then with that objective by setting national targets for annual gas emissions which will reduce aggregate global flows of greenhouse gases and eventually stabilize the stock (Lloyd 2012: 11). Yet, with this clear objective there is no agreement in sight. 'The 2016 Paris Agreement seeks to accelerate and intensify the actions and investment needed for a sustainable low carbon future. Its central aim is to strengthen the global response to the threat of climate change by keeping a global temperature rise this century well below 2 degrees Celsius above pre-industrial levels and to pursue efforts to limit the temperature increase even further to 1.5 degrees Celsius. The Agreement also aims to strengthen the ability of countries to deal with the impacts of climate change.' (UNFCCC website) Yet it requires all Parties to put forward their best efforts through 'nationally determined contributions' (NDCs) without any bindings nor penalties in case of their nationally determined contributions being too small or unfulfilled for attaining the common objective. The question is how the targets can be achieved without a major binding agreement and penalties in case of non-compliance. According to the New York Times (Tabuchi 2017), the new US administration wants to shrink environmental protection agency spending by 31 percent, and eliminate a quarter of the agency's jobs. The argument of the US Executive is that the reduction of US greenhouse gas emissions anywhere by 26 percent below 2005 agreed in Paris raises energy costs in the US.

There are no legal consequences for not following the agreed guidelines which leaves the field in the space of the private sector and more specifically the financial sector, in the way that temperature increases can be controlled or reduced through the sale of Climate Bonds. Evidence shows the growth in the climate bond market has no sustainable bearing on climate change (OECD Bonds and Climate Change 2016 website).

According to Peter Lloyd from the UN Economic and Social Commission for Asia Pacific, the problem is that the negotiating approach is similar to that of the WTO. This consists of consensus decision-taking, a bottom-up approach and differential treatment of developing countries, and complex modalities...' (Lloyd 2012: 1) As a result large global market imbalances and changes in geopolitical balances have produced a general distrust 
Table 1 G/AND BRICS economies BY GDP measured in PPP as a proportion of the world economy. Source CIA Factbook, IMF Members' Quotas and Voting Power, and IMF Board of Governors, Last Updated: May 05, 2017

\begin{tabular}{|c|c|c|c|c|c|}
\hline & & $\begin{array}{l}\text { International reserves } \\
\text { US\$ billions }\end{array}$ & $\begin{array}{l}\text { GDP in PPP } \\
\text { US\$ billions }\end{array}$ & $\begin{array}{l}\text { GDP in PPP } \\
\% \text { of world }\end{array}$ & IMF votes $\%$ \\
\hline \multicolumn{6}{|c|}{ Top 7 economies } \\
\hline 1 & China & $\$ 3,217$ & $\$ 19,510$ & 14.7 & 6.09 \\
\hline 2 & United States & $\$ 130$ & $\$ 17,970$ & 13.5 & 16.53 \\
\hline 3 & India & $\$ 2,207$ & $\$ 8,027$ & 6.0 & 2.64 \\
\hline 4 & Japan & $\$ 1,261$ & $\$ 4,658$ & 3.5 & 6.16 \\
\hline 5 & Germany & $\$ 193$ & $\$ 3,842$ & 2.9 & 5.32 \\
\hline 6 & Russia & $\$ 378$ & $\$ 3,471$ & 2.6 & 2.59 \\
\hline \multirow[t]{2}{*}{7} & Brasil & $\$ 359$ & $\$ 3,166$ & 2.4 & 2.22 \\
\hline & & & Subtotal & 45.6 & 41.55 \\
\hline \multicolumn{6}{|c|}{ Next 7} \\
\hline 1 & Indonesia & $\$ 103$ & $\$ 2,839$ & 2.1 & 0.95 \\
\hline 2 & Great Britain & $\$ 108$ & $\$ 2,660$ & 2.0 & 4.04 \\
\hline 3 & France & $\$ 144$ & $\$ 2,647$ & 2.0 & 4.04 \\
\hline 4 & México & $\$ 204$ & $\$ 2,220$ & 1.7 & 1.8 \\
\hline 5 & Italy & $\$ 142$ & $\$ 2,174$ & 1.6 & 3.02 \\
\hline 6 & South Korea & $\$ 369$ & $\$ 1,849$ & 1.4 & 1.74 \\
\hline \multirow[t]{2}{*}{7} & Canada & $\$ 75$ & $\$ 1,628$ & 1.2 & 2.22 \\
\hline & & & Subtotal & 12.1 & 17.81 \\
\hline
\end{tabular}

among major parties and an absence of leadership. 'The root of the problem that nations do not see adequate gains from the presently negotiated outcomes is that there is no common or shared vision. The consensus that prevailed for most of the second half of the last century has collapsed.' (Lloyd 2012: 23).

In all three aforementioned cases (trade, finance and climate change), what is clear is that the nations as such have less weight than the private sector actors who have little interest in what the governments are negotiating. They want to make business and not have obligatory regulations on top. The end result is a pronounced trend towards privatizing international governance and the breakup of multilateralism into the resurgence of bilateralism.

\section{The Change in the World Power Structure}

In tandem with the different facets of the crisis of multilateralism, the world economic structure that emerged from World War II has disappeared. What formerly were leading Western economies that had the richest economies in per capita terms, are now countries below the income per capita of tax havens. Similarly, those that used to be the largest economies, in absolute terms, are now below those referred to as the BRICS countries. This has consequences in terms of leadership. The weakness in guidance and security provisions and the lack of new leaders has opened the space for the private sector to enter, more so in the middle of a libertarian revolution where the state is perceived as a hindrance to the market, except if it must rescue the financial sector (Table 1).

The votes of the old G7 countries at the IMF are over represented and add to 41.33 percent of the total votes, while their total GDP borders 26.7 percent of world GDP. The new reality of the seven largest countries is that only one European nation is included among them (Germany), which brings with it a new world scenario. At the same time the fact that four of those countries belong to Asia: Russia, China, India and Japan, puts that region of the world in a new light. Finally, the fact that four of the BRICS are among the top seven countries by size-the one that is not being South Africa, changes the balance of power. To complicate matters, this new economic structure is not reflected in the IMF votes. The reform approved in December 2015 within the US Congress did not reflect the new world economic structure. The reason for this is the loss of presence of Europe. The European G7 member countries weigh 8.5 percent of world GDP measured in Power Purchasing Parity (PPP) terms in December of 2015. They are barely half the size of China and slightly larger than India. Japan, for its part, is over represented at the Fund with three time more votes than presence. This imbalance at the IFIs has introduced changes in all regions 
Table 2 IMF voting distribution by political grouping

\begin{tabular}{lllll}
\hline $\begin{array}{l}\text { Groups of countries } \\
\text { political groupings }\end{array}$ & $\begin{array}{l}\text { International reserves } \\
\text { (bns USD) }\end{array}$ & $\begin{array}{l}\text { GDP en PPP } \\
\text { (bns USD) }\end{array}$ & $\begin{array}{l}\text { GDP in PPP/world GDP } \\
(\%)\end{array}$ & $\begin{array}{l}\text { IMF votes } \\
(\%)\end{array}$ \\
\hline G7 & $\$ 2,206$ & $\$ 35,579$ & 26.7 & 41.33 \\
BRICS +2 & $\$ 5,156$ & $\$ 41,082$ & 30.9 & 18.03 \\
Total & & & 57.6 & 59.36 \\
\hline
\end{tabular}

Own calculations using: IMF Members' Quotas and Voting Power, and IMF Board of Governors, Last Updated: May 05, 2017 with a deep search for a more balanced and fair economic system and with institutions that reflect the needs and power structure of the region. In this sense, there is a major shift towards the privatization of governance and also towards regionalization. The exception seems to be Latin America where during the first decade of the new century, regionalization was associated with progressive Governments that wanted integration without the United States, like Europe, Asia and the Gulf countries. Latin American conservative governments aligned themselves with the US through Pan-American regionalization and US Free Trade Agreements, instead.

If we look at the change in terms of the $\mathrm{G} 7$ and the BRICS plus 2, then the situation has changed even more significantly. The gross imbalance is evident when the G7 with slightly over a quarter of world GDP control half of the votes at the IMF plus the US veto while the now called emerging economies since 1981, have a third of world GDP but 10 percent of the votes. This disproportion is a reflection of the former balance of power but no longer reflects the growing changes and the economic importance of the new actors (Table 2).

\section{The Private Sector Response to the Changes}

In the US, however, the role of private corporations within the multilateral system has grown enormously. The United Nations Foundation (UNF), for example, is a part of this privatization process. Some of UNF corporate partners are: Bank of America; CEMEX; Deutsche Bank; Dow Corning; ExxonMobil; The GAVI Alliance ${ }^{1}$; Goldman Sachs; Google's innovative search technologies; IEEE, The Institute of

\footnotetext{
1 The GAVI Alliance (formerly the Global Alliance for Vaccines and Immunisation) is a public-private partnership funded by governments, corporations, foundations, and private individuals. Some of the private sector agents are: Anglo American plc; Bill \& Melinda Gates Foundation; The Children's Investment Fund Foundation (UK); Comic Relief; Dutch Postcode Lottery; ELMA Vaccines and Immunization Foundation; International Federation of Pharmaceutical Wholesalers' (IFPW); JP Morgan; 'la Caixa' Foundation; LDS Charities; Lions Club International Foundation (LCIF); OPEC Fund for International Development (OFID); Other private donors.
}

Electrical and Electronics Engineers, Inc; International Copper Association with 43 mining firms associated ${ }^{2}$; Deere \& Company; Johnson \& Johnson; The Nike Foundation; Shell, amongst the biggest TNCs.

The UNF with its broad private sector funding had an incidence on what the UN system did in terms of the Millennium Development Goals and will continue to have significant influence with the new Sustainable Development Goals (SDGs). In brief, what is occurring is that multilateral agencies are being sponsored by large corporations rather than being supported solely by nations as was the case before 1980. This has generated the change from the inter-national to the global in terms of markets. The multilateral system is increasingly more market-based and less nationally-based. This shift to private funding plus the shift in the private agenda gives signs that policy discussions and decisions related to global public goods (health, education, and the environment) are being faced with private interests in mind.

Globalism weakens US leadership while bilateralism is better from the local point of view. The corporate sector holds a private self-regulating view on global public goods. The complication is that global governance, however private, and the US are on a collision course, says Ruggie (2004), because the global governance agenda is more crowded and diverse, and projects itself more deeply into the sphere of the domestic policies of the State. No matter how much it becomes privatized, the question of how much the global governance agenda sips into the domestic US

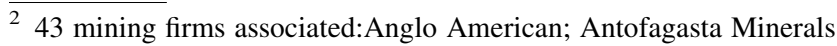
S.A.; Aurubis; BHP Billiton Plc; Boliden AB; Buenavista del Cobre, S.A. de C.V.; Chinalco Luoyang; Compañia Minera Doña Inez Collahuasi; Compañía Minera Zaldívar; CODELCO-Chile; Daechang Co., Ltd.; Freeport McMoRan Inc.; Glencore; Golden Dragon Precise Copper Tube; Halcor S.A.; Kennecott Utah Copper Corp.; KGHM Polska Miedź S.A.; KME; LS-Nikko Copper Inc.; Luvata; Méxicana de Cobre, S.A. de C.V.; Minera Alumbrera Ltd.; Minera Antamina S.A.; Minera Centinela; Minera Escondida Limitada; Minera Los Pelambres; Mitsubishi Materials Corporation; Mueller Industries; Nexans; Outotec Oyj; Palabora; Pan Pacific Copper; Revere Copper Products, Inc.; Rio Tinto Plc; Sociedad Contractual Minera el Abra; Sociedad Minera Cerro Verde S.A.A.; Southern Copper Corporation; Sumitomo Metal Mining Co., Ltd.; Teck; Tenke Fungurume; Wieland-Werke AG; Yunnan Copper Industry (Group) Co., Ltd.
} 
agenda leads to conflict. This is Bolton's point when he says:

Should we, therefore, take global governance "seriously?" Sadly, the answer is yes, not only today but far into the foreseeable future. It is well past the point when the unrestrained and uncritical acceptance of Globalist slogans ("global solutions for global problems") can be allowed to proceed. The costs to the United States reduced constitutional autonomy, impaired popular sovereignty, and reduction of our international power, and limitations on our domestic and foreign policy options and solutions-are far too great, and the current understanding of these costs far too limited to be acceptable. (Bolton 2000: 221)

To overcome these limitations, bilateral instrument that serve the American interest have been developed such as the concept of BITs between the United States Government and each country that wants a treaty individually. This lies at the basis of the privatization of governance. A bilateral policy that serves the American interest is the concept of bilateral free trade agreements. They lie as the essence of the death of multilateralism and public governance and have helped the US recover its leadership through the private sector.

In sum, there is an attempt to regulate global public goods through a private global system. The multilateral system created with the Pax Americana after WWII, e.g. UN system and IFIs, the WTO and the more recent UNFCCC have become ineffective. The strengthening of new national actors and the rebalance of world power after the demise of the Soviet bloc through the presence of the BRICS has changed the world scenario. A market-led economy is bringing alongside a 'market-ruled' governance as the new and future institutional framework. Yet this generates deep contradictions when global public goods that need to be protected are at stake. Further contradictions are raised when global rules intersect with bilateral rules and local rules. The multilateral trade system has been replaced by a bilateral one with strong private sector dominance in conflict resolution. The debt workout mechanism is being replaced by collective action clauses and local creditor laws and the UNFCCC seems incapable of placing sanctions on nations that do not comply with the anti-climate warming agreements. The multilateral system of governance is reshaping into a bilateral and private governance system that can hardly address the challenging problems facing global public goods in the new century.

\section{References}

Bolton, John R. 2000. Should we take global governance seriously? Chicago Journal of International Law 1 (2): 205-221. http:// chicagounbound.uchicago.edu/cjil/vol1/iss $2 / 2$.

Ceaser, James W. 2012. The origins and character of American exceptionalism. American Political Thought 1 (1): 3-28.

Griffith-Jones, Stephany. 1988. La Condicionalidad Cruzada o la Expansión del Ajuste Obligatorio, en: Pensamiento Iberoamericano, 67-90. ISSN: 0212-0208.

Henderson, J., P. Dicken, M. Hess, N. Coe, and H. Wai-Chung Yeung. 2002. Global production networks and the analysis of economic development. Review of International Political Economy 9 (3): 436-464.

International Capital Market Association. 2013. ICMA Sovereign Bond Consultation Paper, New York, December. http://www. icmagroup.org/assets/documents/Maket-Practice/Regulatory-Pol icy/Sovereign-Debt-Information/ICMA-Sovereign-Bond-Consul tation-Paper-79801-5-863-v1-8-161213.pdf.

Kobrin, S.J. 1999. Back to the future: Neomedievalism and the postmodern digital world economy. In Globalization and governance, ed. Aseem Prakash, and Jeffrey A. Hart. London and New York: Routledge.

Krauthammer, Charles. 1991. The unipolar moment. Foreign Affairs 70 (1): 23-33, America and the World 1990/91, Council on Foreign Relations.

Khor, Martin. 1996. Trade and investment: Fighting over investors' rights at WTO. Third World Network. http://www.twn.my/title/ right-cn.htmon. 03 May 2017.

Lloyd, Peter. 2012. Multilateralism in crisis. UN ESCAP, AWP No. 114 , July.

Monteiro, Nuno P. 2014. Theory of unipolar politics. Cambridge: Cambridge Studies in International Relations.

Mosely, Paul, Jane Harrigan, and John Toye. 1991. Aid and power: The World Bank and policy-based lending, vol. 2. London: Routledge.

Raffer, Kunibert. 1990. Applying chapter 9 insolvency to international debts: An economically efficient solution with a human face. World Development 18 (2): 301-311.

Ruggie, John Gerard. 1992. Multilateralism: The anatomy of an institution. International Organization 46 (3): 561-598.

Ruggie, John Gerard. 2004. American exceptionalism, exemptionalism and global governance, KSG Faculty Research Working Papers Series RWP04-006, February.

Tabuchi, Hiroko. 2017. What's at stake in Trump's proposed E.P.A. cuts. The New York Times, 10 April.

Tieleman, Katia. 2000. The failure of the multilateral agreement on investment (MAI) and the absence of a global public policy network. Case Study for the UN Vision Project on Global Public Policy Networks.

The United Nations Framework Convention on Climate Change. 1994. United Nations, FCC/INFORMAL. Available http:// unfccc.int/files/essential_background/convention.

Toye, J.F.J., and R. Toye. 2004. The UN and global political economy, trade, finance, and development. Bloomington, IN: Indiana University Press.

Ugarteche, Oscar and Alberto Acosta. 2007. Global Economy Issues and the International Board of Arbitration for Sovereign Debt. El Norte-Finnish Journal of Latin American Studies No. 2, December, University of Helsinki.

Wohlforth, W. 1999. The stability of a unipolar world. International Security 24 (1): 5-41. 